\title{
PRESIPITASI LOGAM BERAT LIMBAH CAIR LABORATORIUM MENGGUNAKAN NATRIUM SULFIDA DARI BELERANG ALAM
}

\author{
Wisni Rona Anami, Mamay Maslahat, Dian Arrisujaya* \\ Program Studi Kimia, Fakultas MIPA, Universitas Nusa Bangsa, \\ Jl. Sholeh Iskandar Km 4, Tanah Sareal, Bogor 16166, Indonesia \\ *e-mail: arrisujaya@unb.ac.id
}

\begin{abstract}
Precipitation of Laboratory Wastewater Heavy Metals by Natural Sulphur Sodium Sulfide

Sodium sulfide $\left(\mathrm{Na}_{2} \mathrm{~S}\right)$ from natural sulfur has been used for heavy metal precipitation from laboratory wastewater. Heavy metals in laboratory wastewater include mercury ( $\mathrm{Hg})$, lead $(\mathrm{Pb})$, chromium $(\mathrm{Cr})$ and zinc $(\mathrm{Zn})$. Initial laboratory wastewater testing was performed by measuring the initial $\mathrm{pH}$ and the concentration of heavy metals in the wastewater prior to precipitation using the atomic absorption spectrophotometer. Sulphide precipitation phase consists of variations in the concentration of $\mathrm{NaOH}$, time, temperature, and volume of dissolving $\mathrm{Na}_{2} \mathrm{~S}$. Parameters for the efficiency of $\mathrm{Hg}, \mathrm{Pb}, \mathrm{Zn}$ and $\mathrm{Cr}$ heavy metal precipitation were the initial $\mathrm{pH}$, concentration and rate of stirring of the solution. Results showed that the optimum precipitation efficiency for Zn is achieved by using $10 \% \mathrm{Na}_{2} \mathrm{~S}$ solution with an efficiency of $97.93 \%$. The most significant reduction in $\mathrm{Cr}$ and $\mathrm{Hg}$ was the use of $20 \% \mathrm{Na}_{2} \mathrm{~S}$ solution with a precipitation efficiency of $99.24 \%$ and $99.76 \%$ respectively. The optimal efficiency for Pb with a $30 \% \mathrm{Na}_{2} \mathrm{~S}$ solution was $99.68 \%$. Natural sulfur can reduce the levels of heavy metals in laboratory wastewater by precipitation.
\end{abstract}

Key words: Natural sulfur, Heavy metals, Precipitation, Sodium sulfide,

\begin{abstract}
ABSTRAK
Presipitasi logam berat dari limbah cair laboratorium telah dilakukan dengan menggunakan natrium sulfida $\left(\mathrm{Na}_{2} \mathrm{~S}\right)$ dari belerang alam. Logam berat yang terkandung dalam limbah cair laboratorium diantaranya adalah merkuri $(\mathrm{Hg})$, timbal $(\mathrm{Pb})$, kromium $(\mathrm{Cr})$ dan seng $(\mathrm{Zn})$. Pengujian awal limbah laboratorium dilakukan dengan mengukur $\mathrm{pH}$ awal dan kadar logam berat yang terdapat dalam limbah sebelum presipitasi menggunakan $\mathrm{pH}$ meter dan spektrofotometer serapan atom. Tahapan presipitasi limbah oleh sulfida meliputi pembuatan variasi konsentrasi $\mathrm{NaOH}$, waktu, suhu, dan volume pelarutan $\mathrm{Na}_{2} \mathrm{~S}$. Parameter efisiensi presipitasi logam $\mathrm{Hg}, \mathrm{Pb}, \mathrm{Zn}$, dan Cr meliputi pH, Konsentrasi dan Kecepatan pengadukan. Hasil penelitian menunjukkan efisiensi pengendapan optimal untuk logam $\mathrm{Zn}$ terdapat pada penggunaan larutan $\mathrm{Na}_{2} \mathrm{~S} 10 \%$ dengan efisiensi 97,93\%. Larutan $\mathrm{Na}_{2} \mathrm{~S} 20 \%$ paling banyak menurunkan logam $\mathrm{Cr}$ dan $\mathrm{Hg}$ dengan efisiensi masing-masing sebesar 99,24\% dan99,76\%. Efisiensi optimal untuk logam $\mathrm{Pb}$ berada pada penggunaan larutan $\mathrm{Na}_{2} \mathrm{~S} 30 \%$ dengan efisiensi 99,68\%. Belerang alam mampu menurunkan kadar logam berat dalam limbah cair laboratorium dengan metode presipitasi.
\end{abstract}

Kata kunci: Belerang alam, Logam berat, Presipitasi, Natrium sulfida

\section{PENDAHULUAN}

Limbah cair laboratorium mengandung kontaminan dari residu bahan baku, residu pelarut, limbah produk, pencucian dan pembilasan peralatan, serta sisa hasil analisis dari laboratorium itu sendiri. Salah satu bahan cemaran yang terdapat dalam limbah laboratorium adalah logam berat seperti merkuri $(\mathrm{Hg})$, timbal $(\mathrm{Pb})$, kromium (Cr) dan seng ( $\mathrm{Zn}$ ). Logam berat diklasifikasikan sebagai limbah B3 yang pada kadar tertentu dapat membahayakan lingkungan sekitar karena beracun bagi hewan dan manusia (La Grega, 2001). Sumber limbah bahan berbahaya dan beracun (B3) terdiri dari sumber mayor seperti contohnya limbah industri dan minor dengan contohnya adalah limbah dari laboratorium riset dan komersial yang ada umumnya limbah berbentuk cair (Sidik dan Damanhuri, 2012).

Logam berat bersifat toksik karena tidak dapat didegradasi oleh organisme di lingkungan (Widowati et al, 2008). Urutan toksisitas logam berat yang menimbulkan gangguan kesehatan manusia adalah $\mathrm{Hg}>$ $\mathrm{Cd}>\mathrm{Ag}>\mathrm{Ni}>\mathrm{Pb}>\mathrm{As}>\mathrm{Cr}>\mathrm{Sn}>\mathrm{Zn}$ 
(Munfarida, 2016). Logam berat yang masuk ke lingkungan atau masuk ke dalam tubuh manusia tidak dapat dihancurkan, namun tetap akan menumpuk dan mencemari lingkungan atau meracuni tubuh manusia. (Lusiani, 2011). Kandungan logam berat dalam limbah harus di bawah nilai ambang batas yaitu untuk $\mathrm{Hg} 0,002 \mathrm{mg} / \mathrm{L}, \mathrm{Pb} 0,1$ $\mathrm{mg} / \mathrm{L}, \quad \mathrm{Zn} 5 \mathrm{mg} / \mathrm{L}$, dan $\mathrm{Cr} \quad 0,5 \mathrm{mg} / \mathrm{L}$ berdasarkan Peraturan menteri lingkungan hidup nomor 5 tahun 2014.

Salah satu cara untuk menurunkan kadar logam berat adalah dengan cara presipitasi. Penggunaan proses presipitasi adalah untuk menciptakan kondisi di mana terdapat padatan yang tidak dapat larut (Ismayana, 1997). Ada beberapa metode presipitasi logam yaitu pengendapan oleh hidroksida, sulfida dan karbonat. Setiap metode memiliki kelebihan dan kekurangan (Andaka, 2008). Metode hidroksida dan karbonat lebih sederhana dan lebih ekonomis dengan menggunakan $\mathrm{pH}$ yang lebih spesifik (Amer, 1998). Akan tetapi, endapan yang terbentuk sangat kecil, dan koagulan masih perlu ditambahkan untuk membentuk endapan yang lebih besar, sehingga proses pengurangan kandungan logam dapat ditingkatkan (Andaka, 2008).

Metode presipitasi menggunakan sulfida seperti natrium sulfida $\left(\mathrm{Na}_{2} \mathrm{~S}\right)$ yang ditambahkan secara bertahap ke air limbah untuk membentuk logam sulfida yang tidak mudah larut. Belerang di alam terdapat sebagai unsur murni atau sebagai mineralmineral sulfida seperti $\mathrm{FeS}_{2}, \mathrm{PbS}, \mathrm{ZnS}$, dan sebagai sulfat $\mathrm{CaSO}_{4} \cdot 2 \mathrm{H}_{2} \mathrm{O}$ dan $\mathrm{MgSO}_{4} \cdot 7 \mathrm{H}_{2} \mathrm{O}$. Urutan kecepatan pengedapan sulfida berdasarkan nilai Ksp yaitu $\mathrm{HgS}\left(1 \times 10^{-54}\right), \mathrm{PbS}\left(1 \times 10^{-28}\right), \mathrm{ZnS}(1$ $\left.\times 10^{-23}\right)$, dan $\mathrm{Cr}_{2} \mathrm{~S}_{3} \quad\left(1 \times 10^{-20}\right)$. Adapun faktor-faktor yang mempengaruhi kelarutan yaitu suhu, $\mathrm{pH}$, sifat pelarut, efek ion sejenis,, pengaruh aktivasi, pengaruh hidrolisis dan efek kompleks (Day dan Underwood, 2002).

Metode presipitasi dipilih untuk menurunkan kadar logam berat karena memiliki beberapa keunggulan yaitu penanganan yang mudah, konsentrasi akhir yang rendah, biaya yang relatif murah dan bahan-bahan presipitan yang digunakan juga mudah diperoleh (Handoko et al., 2013). $\mathrm{Na}_{2} \mathrm{~S}$ dipilih sebagai agen presipitan dalam presipitasi sulfida karena efisiensinya yang tinggi dan stabilitasnya yang lebih baik (Hagemann et al., 2014).

\section{BAHAN DAN METODE}

\section{Bahan dan Alat}

Bahan-bahan yang digunakan dalam penelitian meliputi bahan uji dan bahan kimia. Bahan uji yang digunakan adalah belerang dan limbah laboratorium. Bahan kimia yang digunakan adalah larutan penyangga $\mathrm{pH}, \mathrm{NaOH} 10,20$ dan $30 \%$, $\mathrm{HNO}_{3} 67 \%$. Alat-alat yang digunakan dalam penelitian ini adalah alat-alat gelas, neraca analitik, magnetic stirrer, $\mathrm{pH}$ meter (HANNA HI 83141), Spektrofotometer Serapan Atom (GBC Avanta), Spektrofotometer Serapan Atom (GBC $\mathrm{Hg}$ 3000), hotplate, dan kertas saring $0,45 \mu \mathrm{m}$.

\section{Optimum Pembuatan Larutan $\mathrm{Na}_{2} \mathrm{~S}$}

Konsentrasi NaOH optimum terhadap waktu pelarutan $\mathrm{Na}_{2} \mathrm{~S}$

Belerang yang telah dihaluskan dengan ukuran 30 mesh ditimbang sebanyak 10, 20 dan 30 gram masing-masing sebanyak tiga kali ulangan. Kemudian dilarutkan ke dalam $\mathrm{NaOH}$ dengan konsentrasi 10, 20, dan 30\%. Larutan ini merupakan larutan $\mathrm{Na}_{2} \mathrm{~S}$ dengan konsentrasi 10, 20, dan 30\%. Pelarutan dilakukan dengan pemanasan di atas hotplate pada suhu $100^{\circ} \mathrm{C}$ sambil diaduk dengan batang pengaduk dan dicatat waktu pelarutan $\mathrm{Na}_{2} \mathrm{~S}$. Kondisi optimal pelarutan dilihat dari penggunaan konsentrasi $\mathrm{NaOH}$ yang dapat melarutkan belerang paling cepat untuk masing-masing konsentrasi $\mathrm{Na}_{2} \mathrm{~S} 10,20$, dan $30 \%$.

\section{Kondisi suhu optimum pelarutan $\mathrm{Na}_{2} \mathrm{~S}$}

Belerang yang telah dihaluskan dengan ukuran 30 mesh ditimbang sebanyak 10, 20, dan 30 gram masing-masing sebanyak tiga kali ulangan kemudian dilarutkan ke dalam $\mathrm{NaOH}$ yang memberikan waktu pelarutan paling cepat pada percobaan pertama, larutan ini menghasilkan $\mathrm{Na}_{2} \mathrm{~S}$ dengan konsentrasi 10, 20, dan 30\%. Setelah itu 
larutan $\mathrm{Na}_{2} \mathrm{~S} 10 \%$ dipanaskan pada suhu 80, 100 , dan $120{ }^{\circ} \mathrm{C}$. Begitu juga dengan larutan $\mathrm{Na}_{2} \mathrm{~S} 20$ dan $30 \%$. Kondisi optimum suhu dilihat dari suhu yang dapat melarutkan paling cepat pada konsentrasi $\mathrm{Na}_{2} \mathrm{~S} 10,20$, dan $30 \%$.

Konsentrasi $\mathrm{NaOH}$ optimum terhadap volume penambahan larutan $\mathrm{Na}_{2} \mathrm{~S}$

Belerang yang telah dihaluskan dengan ukuran 30 mesh ditimbang sebanyak 10, 20, dan 30 gram masing-masing sebanyak tiga kali. Kemudian dilarutkan ke dalam $\mathrm{NaOH}$ 10, 20, dan 30\%. Larutan ini memiliki konsentrasi $\mathrm{Na}_{2} \mathrm{~S}$ sebesar 10, 20, dan $30 \%$. Setelah itu larutan $\mathrm{Na}_{2} \mathrm{~S}$ ini ditambahkan ke dalam $250 \mathrm{~mL}$ sampai mencapai $\mathrm{pH}$ optimal proses presipitasi sulfida yaitu 10. Dicatat konsentrasi $\mathrm{NaOH}$ yang memberikan volume penambahan paling sedikit untuk masing- masing konsentrasi $\mathrm{Na}_{2} \mathrm{~S}$.

\section{Optimasi efisiensi presipitasi}

Pengaruh konsentrasi $\mathrm{Na}_{2} \mathrm{~S}$ dan $\mathrm{pH}$ terhadap efisiensi presipitasi

Larutan $\mathrm{Na}_{2} \mathrm{~S}$ dengan konsentrasi $10 \%$ ditambahkan ke dalam $250 \mathrm{~mL}$ sampel limbah laboratorium sampai $\mathrm{pH}$ akhir mencapai 5 sambil dilakukan pengadukan dengan kecepatan $40 \mathrm{rpm}$. Hal yang sama dilakukan untuk pH akhir 7 dan 10 dengan konsentrasi $\mathrm{Na}_{2} \mathrm{~S}$ yang sama. Langkah tersebut diulangi untuk $\mathrm{Na}_{2} \mathrm{~S}$ dengan konsentrasi 20 dan 30\%. Endapan yang terbentuk dibiarkan turun, lalu filtratnya disaring dan diukur kadar logam $\mathrm{Hg}, \mathrm{Pb}, \mathrm{Zn}$, dan Cr. Sebelum analisis dilakukan destruksi untuk menghilangkan atau memisahkan kandungan ion lain.

\section{Pengaruh Kecepatan Pengadukan terhadap} Efisiensi Presipitasi

Sampel limbah cair laboratorium yang telah ditambahkan larutan $\mathrm{Na}_{2} \mathrm{~S} 30 \%$ yang dibuat hingga $\mathrm{pH}$ akhir mencapai 10 dilakukan variasi kecepatan pengadukan. Kecepatan pengadukan yang digunakan mulai dari 40, 70, dan $100 \mathrm{rpm}$. Kemudian diukur konsentrasi logam $\mathrm{Hg}, \mathrm{Pb}, \mathrm{Zn}$ dan $\mathrm{Cr}$ dengan menggunakan spektrofotometri serapan atom dan dihitung efisiensi presipitasinya.

\section{Perhitungan efisiensi presipitasi logam berat}

Efisiensi presipitasi logam berat $\mathrm{Hg}, \mathrm{Pb}, \mathrm{Zn}$ dan $\mathrm{Cr}$ dalam limbah laboratorium lngkungan dapat dihitung dengan rumus sebagai berikut:

$$
\% E=\frac{C o-C i}{C i} \times 100 \%
$$

Keterangan:

Co : Konsentrasi logam awal

$\mathrm{Ci}$ : Konsentrasi logam setelah presipitasi

$\% \mathrm{E}$ : Efisiensi presipitasi logam

\section{HASIL DAN PEMBAHASAN}

\section{Karakteristik Limbah Logam Berat}

Pengujian $\mathrm{pH}$ limbah logam berat laboratorium diukur dengan menggunakan pH meter, sedangkan kadar logam berat diukur dengan menggunakan spektrofotometri serapan atom. Logam $\mathrm{Hg}$ dianalisa kadarnya menggunakan spektrofotometri serpan atom uap dingin, sedangkan logam $\mathrm{Pb}, \mathrm{Zn}$, dan $\mathrm{Cr}$ dianalisa kadarnya menggunakan spektrofotometri serapan atom metode nyala. Kadar logam $\mathrm{Hg}, \mathrm{Pb}, \mathrm{Zn}$, dan $\mathrm{Cr}$ setelah dianalisa kemudian dibandingkan dengan baku mutu yaitu Peraturan Menteri Lingkungan Hidup Nomor 5 tahun 2014 lampiran XLVII. Kadar logam yang diukur kadarnya adalah merkuri $(\mathrm{Hg})$, timbal $(\mathrm{Pb})$, seng $(\mathrm{Zn})$, dan kromium (Cr). Hasil dari pengujian awal limbah laboratorium dapat dilihat pada Tabel 1.

Tabel 1 Kondisi Awal Limbah Laboratorium Sebelum Presipitasi

\begin{tabular}{cccc}
\hline Parameter & Nilai & Baku Mutu & Satuan \\
\hline $\mathrm{pH}$ & 2 & $6-9$ & - \\
Merkuri $(\mathrm{Hg})$ & 74,192 & 0,002 & $\mathrm{mg} / \mathrm{L}$ \\
Seng $(\mathrm{Zn})$ & 17,718 & 5 & $\mathrm{mg} / \mathrm{L}$ \\
Timbal $(\mathrm{Pb})$ & 210,451 & 0,1 & $\mathrm{mg} / \mathrm{L}$ \\
Kromium $(\mathrm{Cr})$ & 57,427 & 0,5 & $\mathrm{mg} / \mathrm{L}$ \\
\hline
\end{tabular}


Tabel 1. menunjukkan kondisi awal limbah laboratorium sebelum dilakukan presipitasi. $\mathrm{pH}$ limbah laboratorium berada pada kondisi asam yaitu $\mathrm{pH}$ 2. Limbah dngan $\mathrm{pH}$ asam tidak boleh langung dibuang ke perairan. Namun kondisi $\mathrm{pH}$ yang asam ini merupakan kondisi yang sesuai untuk memulai proses presipitasi. Proses presipitasi paling baik dilakukan pada kondisi $\mathrm{pH}$ 2-3 karena pada $\mathrm{pH}$ tersebut logam memiliki kelarutan yang tinggi dan dalam keadaan bebas sehingga mungkin diendapkan (Lusiani, 2011). Logam berat pada limbah laboratorium sebelum presipitasi memiliki kadar yang tinggi dan melebihi baku mutu yang ditetapkan.

Dari data yang diperoleh pada Tabel 1, dapat dilihat urutan kadar logam berat dalam limbah laboratorium dari paling tinggi hingga paling rendah adalah logam timbal $(\mathrm{Pb})$, merkuri $(\mathrm{Hg})$, seng $(\mathrm{Zn})$ dan terakhir logam kromium $(\mathrm{Cr})$. Sumber pencemar logam berat tersebut berasal dari sisa penggunaan bahan baku, sisa-sisa pengujian maupun sisa-sisa dari pencucian peralatan (Lusiani, 2011).

\section{Pengaruh Konsentrasi $\mathrm{NaOH}$ terhadap Waktu Pelarutan $\mathrm{Na}_{2} \mathrm{~S}$}

Efisiensi presipitasi metode sulfida dan hidroksida lebih baik daripada metode karbonat untuk mereduksi kandungan logam $\mathrm{Cr}$, Ni dan $\mathrm{Zn}$ pada limbah industri elektroplating (Naim et. al., 2010). Hasil pengaruh variasi konsentrasi $\mathrm{NaOH}$ terhadap waktu pelarutan $\mathrm{Na}_{2} \mathrm{~S}$ disajikan dalam Gambar 1.

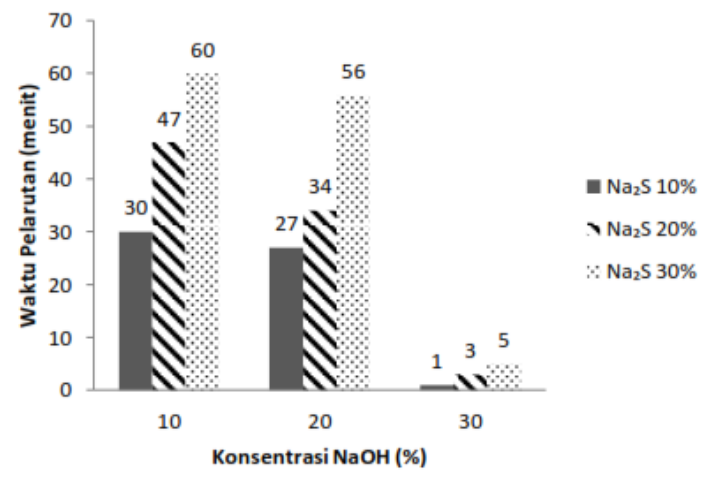

Gambar 1. Pengaruh Konsentrasi $\mathrm{NaOH}$ terhadap Waktu Pelarutan $\mathrm{Na}_{2} \mathrm{~S}$
Konsentrasi $\mathrm{NaOH}$ sangat berpengaruh terhadap waktu pelarutan $\mathrm{Na}_{2} \mathrm{~S}$. Semakin besar konsentrasi $\mathrm{NaOH}$ yang digunakan maka semakin sedikit waktu yang diperlukan untuk melarutkan belerang. Rata-rata waktu pelarutan paling cepat terdapat pada penggunaan konsentrasi $\mathrm{NaOH} 30 \%$. Pembuatan larutan $\mathrm{Na}_{2} \mathrm{~S}$ yang berbeda, membutuhkan waktu pelarutan yang berbeda pula dengan penggunaan konsentrasi $\mathrm{NaOH}$ yang sama. Semakin tinggi konsentrasi $\mathrm{Na}_{2} \mathrm{~S}$ yang dibuat, semakin lama waktu yang dibutuhkan untuk pelarutan.

\section{Pengaruh Variasi Suhu terhadap Waktu Pelarutan $\mathrm{Na}_{2} \mathrm{~S}$}

Variasi suhu juga dibutuhkan untuk melihat efisiensi waktu pembuatan larutan $\mathrm{Na}_{2} \mathrm{~S}$. Semakin tinggi suhu yang digunakan, maka semakin sedikit pula waktu yang dibutuhkan untuk melarutkan suatu bahan (Cucikodana, 2012). Hasil pengaruh variasi terhadap waktu pelarutan disajikan dalam Gambar 2.

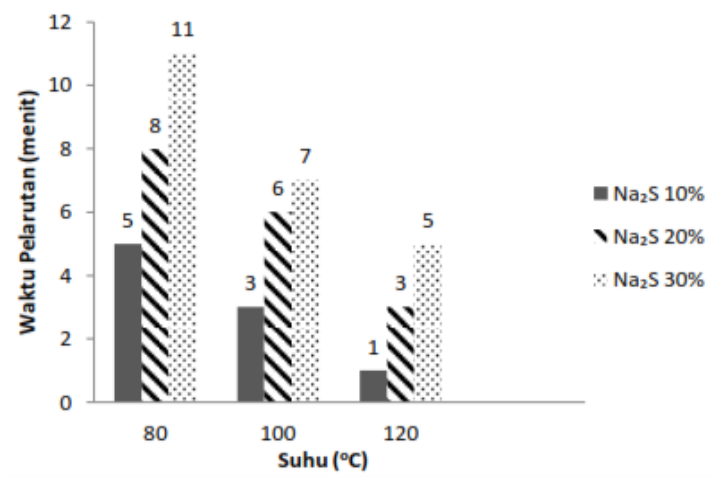

Gambar 2. Pengaruh Variasi Suhu terhadap Waktu Pelarutan $\mathrm{Na}_{2} \mathrm{~S}$

Semakin tinggi suhu yang digunakan, maka semakin sedikit waktu yang diperlukan untuk melarutkan. Rata-rata waktu pelarutan paling cepat terdapat pada penggunaan suhu tertinggi yaitu $120{ }^{\circ} \mathrm{C}$. Waktu yang diperlukan untuk membuat larutan $\mathrm{Na}_{2} \mathrm{~S}$ dengan konsentrasi berbeda pada suhu yang sama juga berbeda. Semakin tinggi konsentrasi $\mathrm{Na}_{2} \mathrm{~S}$ yang akan dibuat maka semakin lama juga waktu yang dibutuhkan utuk melarutkan. 


\section{Pengaruh Konsentrasi $\mathrm{NaOH}$ Terhadap Volume Penambahan $\mathrm{Na}_{2} \mathrm{~S}$}

Belerang dapat larut di dalam larutan $\mathrm{NaOH}$ dengan disertai pemanasan dan pengadukan. Hasil pengaruh konsentrasi $\mathrm{NaOH}$ terhadap volume penambahan larutan $\mathrm{Na}_{2} \mathrm{~S}$ dapat dilihat pada Gambar 3 .

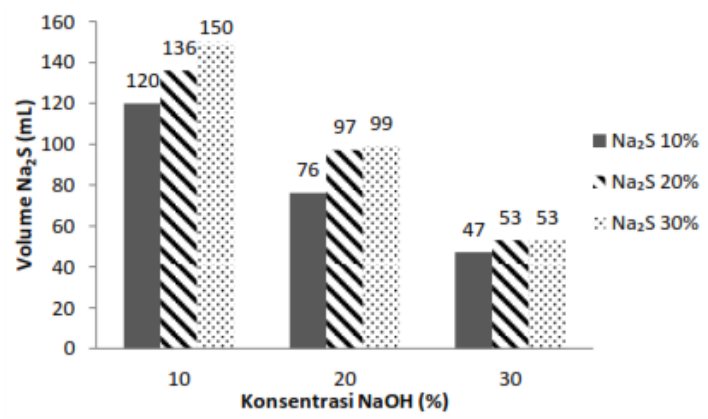

Gambar 3. Pengaruh Konsentrasi $\mathrm{NaOH}$ terhadap Volume Penambahan $\mathrm{Na}_{2} \mathrm{~S}$

Pembuatan larutan $\mathrm{Na}_{2} \mathrm{~S}$ dilakukan disertai dengan pemanasan di atas hotplate karena suhu dapat mempercepat kelarutan. Dari Gambar 3. dapat dilihat bahwa semakin tinggi konsentrasi $\mathrm{NaOH}$ yang digunakan maka semakin sedikit volume larutan $\mathrm{Na}_{2} \mathrm{~S}$ yang digunakan untuk mengendapkan sampel. Semakin sedikit volume $\mathrm{Na}_{2} \mathrm{~S}$ yang ditambahkan untuk mengendapkan sampel maka semakin efektif proses presipitasi yang terjadi. Konsentrasi $\mathrm{NaOH} 30 \%$ paling efektif karena volume yang ditambahkan untuk mengendapkan logam di dalam limbah laboratorium lebih sedikit dibandingkan dengan penggunaan $\mathrm{NaOH}$ konsentrasi $10 \%$ dan $20 \%$.

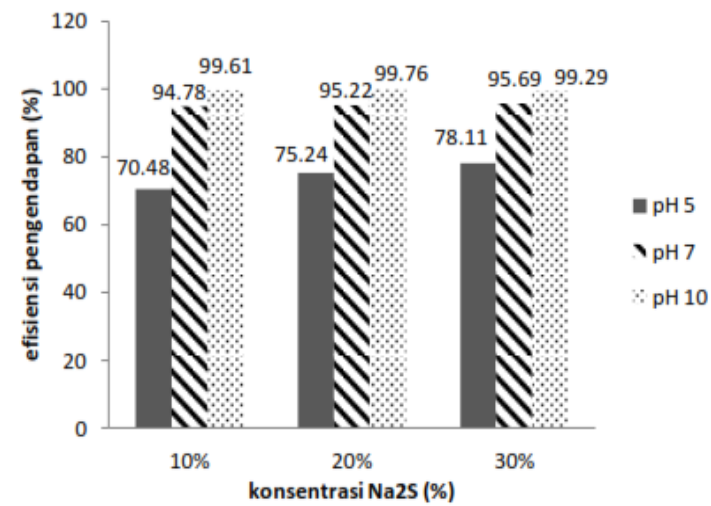

Gambar 4. Pengaruh Konsentrasi $\mathrm{Na}_{2} \mathrm{~S}$ dan Variasi $\mathrm{pH}$ terhadap Efisiensi Presipitasi $\mathrm{Hg}$

Pengaruh Konsentrasi $\mathrm{Na}_{2} \mathrm{~S}$ dan $\mathrm{pH}$ terhadap Efisiensi Presipitasi

Pengaruh Konsentrasi $\mathrm{Na}_{2} \mathrm{~S}$ dan $\mathrm{pH}$ terhadap Efisiensi Presipitasi $\mathrm{Hg}$

Konsentrasi $\mathrm{NaOH}$ sebesar $30 \%$ dipilih karena paling efektif digunakan untuk melarutkan belerang. Hal tersebut dapat dilihat dari waktu pelarutan belerang yang lebih singkat dan volume penambahan larutan $\mathrm{Na}_{2} \mathrm{~S}$ yang lebih sedikit dipakai untuk mengendapkan logam. Pengaruh konsentrasi $\mathrm{Na}_{2} \mathrm{~S}$ dan variasi $\mathrm{pH}$ terhadap efisiensi presipitasi merkuri dapat dilihat pada Gambar 4.

Semakin tinggi konsentrasi $\mathrm{Na} 2 \mathrm{~S}$ yang digunakan, semakin besar efisiensi presipitasi yang terjadi. Hal ini dapat disebabkan karena semakin tinggi konsentrasi $\mathrm{Na}_{2} \mathrm{~S}$, semakin banyak yang dapat bereaksi dengan logam merkuri membentuk endapan. Kecuali pada pH 10, efisiensi presipitasi tertinggi terjadi pada konsentrasi $\mathrm{Na}_{2} \mathrm{~S} 20 \%$ dan turun kembali pada konsentrasi $\mathrm{Na}_{2} \mathrm{~S} 30 \%$. Dimungkinkan pada konsentrasi $\mathrm{Na}_{2} \mathrm{~S} 30 \%$ kondisi larutan sudah lewat jenuh sehingga endapan terlepas kembali. Selain pengaruh dari larutan $\mathrm{Na}_{2} \mathrm{~S}$, endapan dapat juga terbentuk dengan ion hidroksida dikarenakan larutan $\mathrm{Na}_{2} \mathrm{~S}$ yang digunakan dibuat dengan melarutkan belerang dengan larutan $\mathrm{NaOH}$. Namun endapan yang lebih dulu terbentuk adalah endapan merkuri dengan sulfida dikarenakan Ksp merkuri (II) sulfida lebih kecil dibandingkan Ksp 
merkuri (II) hidroksida. Nilai Ksp $\mathrm{HgS}$ adalah $1 \times 10^{-54}$, sedangkan nilai Ksp untuk $\mathrm{Hg}(\mathrm{OH})_{2}$ adalah 3,6 × $10^{-26}$. Semakin kecil nilai Ksp maka endapan semakin cepat terjadi (Khopkar, 2007). Endapan $\mathrm{HgS}$ yang terbentuk berwarna hitam, sedangkan endapan $\mathrm{Hg}(\mathrm{OH})_{2}$ berwarna putih. Berdasarkan nilai Ksp tersebut maka endapan yang lebih dominan terbentuk adalah endapan $\mathrm{HgS}$ karena nilai Ksp-nya lebih kecil dan warna endapan yang terbentuk dominan berwarna hitam.

Selain konsentrasi $\mathrm{NaS}$, variasi $\mathrm{pH}$ juga berpengaruh terhadap efisiensi presipitasi. Kondisi pH optimum terjadinya pengendapan dengan metode presipitasi sulfida adalah pada rentang $\mathrm{pH}$ 7-9, sedangkan pada $\mathrm{pH}$ lebih besar dari 9 endapan mulai larut kembali (Skants dan Jamali, 2012). Penambahan $\mathrm{Na}_{2} \mathrm{~S}$ secara bertahap akan menggeser kesetimbangan ke kanan sehingga lebih banyak endapan $\mathrm{HgS}$ yang terbentuk. Pada $\mathrm{pH}$ 9, pengendapan mencapai tingkat optimal, sebagian besar logam merkuri terendapkan dengan baik, dan pada $\mathrm{pH}$ di atas 9, jumlah endapan $\mathrm{HgS}$ mulai menurun. Hal ini dapat terjadi karena penambahan ion $\mathrm{S}^{2-}$ yang berlebihan berpotensi membentuk kompleks dengan endapan logam sulfida yang akan melarutkan endapan logam sulfida kembali (Fadlilah, 2018).

Pada saat $\mathrm{pH}$ mencapai 10 endapan masih terbentuk dan larut kembali pada $\mathrm{pH}$ melebihi 10. Gambar 4. menunjukkan semakin tinggi konsentrasi $\mathrm{Na}_{2} \mathrm{~S}$ yang digunakan, maka semakin tinggi efisiensi presipitasinya. Namun, penggunaan sulfida yang berlebihan dapat menyebabkan presipitat logam sulfida larut kembali sebagai kompleks polisulfida logam dalam larutan (Lewis, 2006). Pada pH 5 efisiensi presipitasi rata-rata berada di bawah $80 \%$, $\mathrm{pH}$ ini merupakan $\mathrm{pH}$ awal terbentuknya endapan. Endapan yang terbentuk semakin banyak seiring dengan meningkatnya $\mathrm{pH}$ dan turun kembali saat melewati $\mathrm{pH}$ optimum. Endapan yang terbentuk dari presipitasi sulfida merupakan endapan hitam merkuri (II) sulfida (HgS) (Fadilah, 2018). pH limbah laboratorium pada saat sebelum dilakukan pengendapan berada pada $\mathrm{pH}$ 2. Kondisi proses presipitasi dengan sulfida optimum dimulai pada $\mathrm{pH}$ 2-3. Pada nilai $\mathrm{pH}$ ini, logam memiliki kelarutan yang tinggi dan dalam kondisi bebas sehingga dapat diendapkan (Lusiani, 2011). Nilai pH limbah laboratorium sudah sesuai untuk proses presipitasi sulfida sehingga tidak diperlukan pengkondisian lagi.

\section{Pengaruh Konsentrasi $\mathrm{Na}_{2} \mathrm{~S}$ dan $\mathrm{pH}$ terhadap Efisiensi Presipitasi $\mathrm{Zn}$}

Logam seng dapat direduksi dengan presipitasi menggunakan sulfida karena endapan yang dihasilkan lebih stabil dan mempunyai efisiensi yang tinggi (Hagemann, 2014). Presipitasi sulfida pada percobaan ini menggunakan larutan $\mathrm{Na}_{2} \mathrm{~S}$ dengan konsentrasi berbeda dan variasi $\mathrm{pH}$. Pengaruh konsentrasi $\mathrm{Na}_{2} \mathrm{~S}$ dan variasi $\mathrm{pH}$ terhadap efisiensi presipitasi dapat dilihat pada Gambar 5.

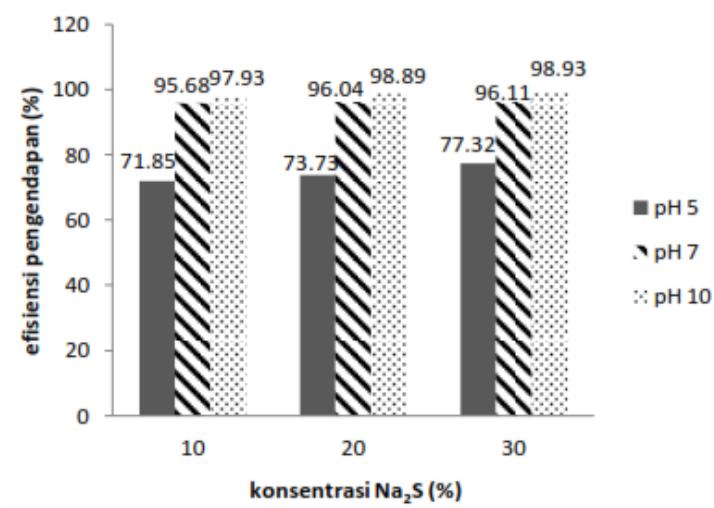

Gambar 5. Pengaruh Konsentrasi $\mathrm{Na}_{2} \mathrm{~S}$ dan Variasi $\mathrm{pH}$ terhadap Efisiensi Presipitasi Zn

Gambar 5. menunjukkan bahwa semakin tinggi konsentrasi $\mathrm{Na} 2 \mathrm{~S}$ yang digunakan maka semakin besar efisiensi presipitasinya. Hal ini karena semakin banyak sulfida yang bereaksi dengan logam Zn membentuk endapan. Endapan yang terbentuk dimungkinkan adalah endapan seng dengan sufida $(\mathrm{ZnS})$ dan endapan seng dengan hidroksida $\left(\mathrm{Zn}(\mathrm{OH})_{2}\right)$. Endapan $\mathrm{ZnS}$ yang terbentuk berwarna putih, sedangkan endapan $\mathrm{Zn}(\mathrm{OH})_{2}$ berbentuk gelatin berwarna 
putih. Endapan $\mathrm{ZnS}$ akan lebih dulu terbentuk dibandingkan dengan endapan $\mathrm{Zn}(\mathrm{OH})_{2}$ karena nilai Ksp $\mathrm{ZnS}$ lebih kecil yaitu $1 \times 10^{-23}$ sedangkan nilai Ksp $\mathrm{Zn}(\mathrm{OH})_{2}$ sebesar $5 \times 10^{-17}$ (Khopkar, 2007). Efisiensi presipitasi logam Zn paling besar terjadi pada penggunaan $\mathrm{Na} 2 \mathrm{~S}$ dengan konsentrasi 30\%. Hal ini karena semakin banyak $\mathrm{Na}_{2} \mathrm{~S}$ bereaksi dengan logam seng membentuk endapan $\mathrm{ZnS}$.

Untuk logam Zn, efisiensi paling tinggi berada pada $\mathrm{pH}$ 10. Semakin tinggi nilai $\mathrm{pH}$ semakin tinggi pula efisiensi presipitasinya. Pada presipitasi dengan sulfida, $\mathrm{pH}$ optimum presipitasinya berada pada pH 9 (Skants dan Jamali, 2012). Pada percobaan yang dilakukan, $\mathrm{pH}$ optimum presipitasinya terdapat pada $\mathrm{pH} 10$ karena pada $\mathrm{pH} 9$ endapan masih terbentuk pada saat ditambahkan larutan $\mathrm{Na}_{2} \mathrm{~S}$. Hasil berbeda dari Skants dan Jamali (2012) yang menyatakan $\mathrm{pH}$ optimum untuk terjadinya presipitasi sulfida pada $\mathrm{pH} 9$. $\mathrm{Hal}$ ini dapat dimungkinkan karena $\mathrm{Na}_{2} \mathrm{~S}$ yang dipakai dalam presipitasi sulfida berasal dari pelarutan belerang dengan $\mathrm{NaOH}$ bukan dari bahan kimia $\mathrm{Na}_{2} \mathrm{~S}$.

Pengaruh Konsentrasi $\mathrm{Na}_{2} \mathrm{~S}$ dan $\mathrm{pH}$ terhadap Efisiensi Presipitasi $\mathrm{Pb}$

Kadar cemaran $\mathrm{Pb}$ dalam limbah laboratorium sangat tinggi yaitu 210,451 $\mathrm{mg} / \mathrm{L}$. Karena itu kadar logam $\mathrm{Pb}$ harus dikurangi sebelum dibuang ke perairan. Logam $\mathrm{Pb}$ dapat direduksi melalui proses presipitasi dengan menggunakan agen presipitat sulfida. Sulfida yang digunakan adalah $\mathrm{Na}_{2} \mathrm{~S}$. Pengaruh konsentrasi $\mathrm{Na}_{2} \mathrm{~S}$ dan variasi $\mathrm{pH}$ terhadap efisiensi presipitasi dapat dilihat pada Gambar 6.

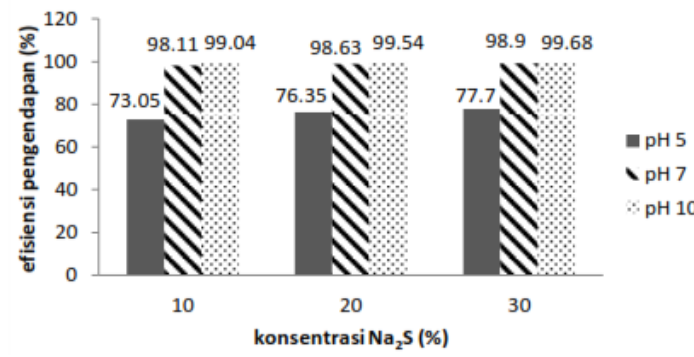

Gambar 6. Pengaruh Konsentrasi $\mathrm{Na}_{2} \mathrm{~S}$ dan Variasi $\mathrm{pH}$ terhadap Efisiensi Presipitasi $\mathrm{Pb}$

Semakin tinggi kadar $\mathrm{Na}_{2} \mathrm{~S}$ yang ditambahkan maka semakin banyak logam $\mathrm{Pb}$ yang dapat diendapkan. Larutan $\mathrm{Na}_{2} \mathrm{~S}$ yang digunakan untuk presipitasi sulfida dibuat dengan melarutkan belerang dengan $\mathrm{NaOH} 30 \%$. Oleh karena itu, endapan yang mungkin terbentuk adalah endapan timbal dengan sulfida $(\mathrm{PbS})$ dan endapan timbal dengan hidroksida $\left(\mathrm{Pb}(\mathrm{OH})_{2}\right)$. Nilai Ksp dari masing- masing endapan sangat berpengaruh terhadap kecepatan pengendapan yang terbentuk. Nilai Ksp dari $\mathrm{PbS}$ adalah $1 \times 10^{-28}$ sedangkan nilai Ksp dari $\mathrm{Pb}(\mathrm{OH})_{2}$ adalah $4 \times 10^{-15}$ (Khopkar, 2007). Endapan yang terbentuk lebih dulu adalah endapan $\mathrm{PbS}$ karena nilai $\mathrm{Ksp} \mathrm{PbS}$ lebih kecil dibandingkan dengan $\mathrm{Pb}(\mathrm{OH})_{2}$. Semakin kecil nilai Ksp maka semakin cepat endapan terbentuk (Day dan Underwood, 2002). Endapan yang dominan terbentuk adalah endapan $\mathrm{PbS}$ dapat dilihat dari warna endapan yang dominan berwarna hitam, sedangkan endapan $\mathrm{Pb}(\mathrm{OH})_{2}$ adalah endapan berwarna putih.

Nilai $\mathrm{pH}$ juga sangat berpengaruh terhadap efisiensi presipitasi. Presipitasi dengan sulfida $\mathrm{pH}$ optimum presipitasinya terjadi pada pH 9 (Skants dan Jamali, 2012). Begitu pula dengan presipitasi menggunakan hidroksida $\mathrm{pH}$ optimumnya terjadi pada $\mathrm{pH}$ 9 dan akan melarut kembali apabila $\mathrm{pH}$ di atas 10 (Adli, 2012). Dari percobaan yang dilakukan, efisiensi presipitasi logam $\mathrm{Pb}$ paling tinggi terjadi pada $\mathrm{pH}$ 10. Pada $\mathrm{pH}$ kurang dari 10 pengendapan masih terjadi pada saat ditambahkan larutan $\mathrm{Na}_{2} \mathrm{~S}$ dan melarut kembali pada $\mathrm{pH}$ melebihi $10 . \mathrm{pH}$ optimum dari percobaan yang dilakukan adalah 10, sedangkan $\mathrm{pH}$ optimum dari referensi yang diacu adalah 9. Hasil ini berbeda bisa dikarenakan $\mathrm{Na}_{2} \mathrm{~S}$ yang digunakan tidak murni melainkan hasil modifikasi dengan cara melarutkan belerang dengan $\mathrm{NaOH}$.

Pengaruh Konsentrasi $\mathrm{Na}_{2} \mathrm{~S}$ dan $\mathrm{pH}$ terhadap Efisiensi Presipitasi $\mathrm{Cr}$ 
Kadar logam $\mathrm{Cr}$ yang terkandung dalam limbah laboratorium sangat tinggi yaitu sebesar 57,427 mg/L. Kadar ini melebihi baku mutu yang ditetapkan oleh peraturan menteri lingkungan hidup nomor 5 tahun 2014 yaitu sebesar 0,5 $\mathrm{mg} / \mathrm{L}$. Presipitasi sulfida dalam pecobaan ini menggunakan variasi konsentrasi $\mathrm{Na}_{2} \mathrm{~S}$ dan $\mathrm{pH}$. Pengaruh konsentrasi $\mathrm{Na}_{2} \mathrm{~S}$ dan variasi $\mathrm{pH}$ terhadap efisiensi presipitasi dapat dilihat pada Gambar 7.

Efisiensi presipitasi paling tinggi terdapat pada penggunaan $\mathrm{Na}_{2} \mathrm{~S} 30 \%$ dengan nilai $\mathrm{pH}$ 10. Pada kondisi ini efisiensi paling tinggi yang dihasilkan adalah sebesar 99,42\%. Kadar logam $\mathrm{Cr}$ dalam limbah laboratorium dapat dikurangi dari 57,427 $\mathrm{mg} / \mathrm{L}$ menjadi $0,189 \mathrm{mg} / \mathrm{L}$. Kadar ini sudah memenuhi baku mutu yang ditetapkan oleh peraturan menteri lingkungan hidup nomor 5 tahun 2014 yaitu sebesar 0,5 mgL. Endapan yang terbentuk dengan logam $\mathrm{Cr}$ adalah endapan $\mathrm{Cr}$ dengan sulfida dan $\mathrm{Cr}$ dengan hidroksida. Namun, berbeda dengan logam $\mathrm{Hg}, \mathrm{Pb}$ dan $\mathrm{Zn}$, endapan yang lebih dulu terbentuk dengan logam $\mathrm{Cr}$ adalah $\mathrm{Cr}(\mathrm{OH})_{3}$. Hal ini disebabkan karena nilai $\mathrm{Ksp} \mathrm{Cr}(\mathrm{OH})_{3}$ lebih kecil dari $\mathrm{Cr}$ dengan sulfida $\left(\mathrm{Cr}_{2} \mathrm{~S}_{3}\right)$. Warna endapan $\mathrm{Cr}(\mathrm{OH})_{3}$ adalah hijau, sedangkan warna endapan $\mathrm{Cr}_{2} \mathrm{~S}_{3}$ adalah hitam kecoklatan. Endapan yang dominan terbentuk adalah endapan $\mathrm{Cr}(\mathrm{OH})_{3}$ ditandai dengan larutan yang berwarna hijau keruh. Nilai Ksp untuk $\mathrm{Cr}(\mathrm{OH})_{3}$ adalah $6,7 \times 10^{-31}$ sedangkan nilai Ksp untuk $\mathrm{Cr}_{2} \mathrm{~S}_{3}$ adalah $1 \mathrm{x}$ $10^{-20}$ (Khopkar, 2007). Nilai pH juga berpengaruh terhadap efisiensi presipitasi. $\mathrm{pH}$ optimal untuk terjadinya endapan $\mathrm{Cr}(\mathrm{OH})_{3}$ berada pada kisaran 8,5- 9,5, sedangkan $\mathrm{pH}$ optimal untuk presipitasi sulfida berada pada pH 9 (Skant dan Jamali, 2012).

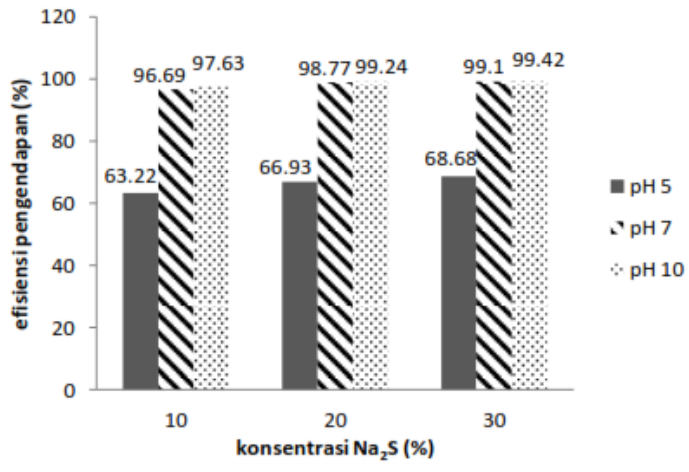

Gambar 7. Pengaruh Konsentrasi Na2S dan Variasi $\mathrm{pH}$ terhadap Efisiensi Presipitasi $\mathrm{Cr}$

Dari percobaan yang dilakukan didapatkan hasil efisiensi paling tinggi pada $\mathrm{pH}$ 10, karena pada saat $\mathrm{pH}$ mencapai 9 masih terjadi pengendapan ketika ditambahkan dengan larutan $\mathrm{Na}_{2} \mathrm{~S}$. Efisiensi presipitasi paling kecil terjadi pada saat $\mathrm{pH}$ mencapai 6. Rata-rata efisiensi berada di bawah 70\%. Hal ini dapat disebabkan karena kandungan logam $\mathrm{Cr}$ masih banyak terdapat di dalam limbah dan belum terendapkan secara sempurna. Ketika $\mathrm{pH}$ dinaikkan menjadi 7, efisiensi presipitasi juga naik karena penambahan larutan $\mathrm{Na}_{2} \mathrm{~S}$ menyebabkan lebih banyak logam $\mathrm{Cr}$ yang terendapkan. Namun kondisi $\mathrm{pH}$ ini belum optimal karena pada saat ditambahkan larutan $\mathrm{Na}_{2} \mathrm{~S}$ masih ada endapan yang terbentuk. $\mathrm{pH}$ mencapai optimal pada saat berada pada $\mathrm{pH} 10$. Endapan yang terbentuk akan melarut kembali apabila $\mathrm{pH}$ larutan melebihi 10, hal ini karena ion hidroksil menjadi lebih banyak sehingga endapan melarut kembali (Asmadi, 2009).

\section{Pengaruh Kecepatan Pengadukan terhadap Efisiensi Presipitasi}

Terdapat beberapa faktor yang mendukung terhadap proses presipitasi, diantaranya adalah bahan kimia yang dipakai untuk menurunkan kadar logam berat (jenis presipitan), dosis presipitan, derajat keasaman $(\mathrm{pH})$, kecepatan pengadukan dan waktu pengendapan (Asri $e t$ al., 2010). 


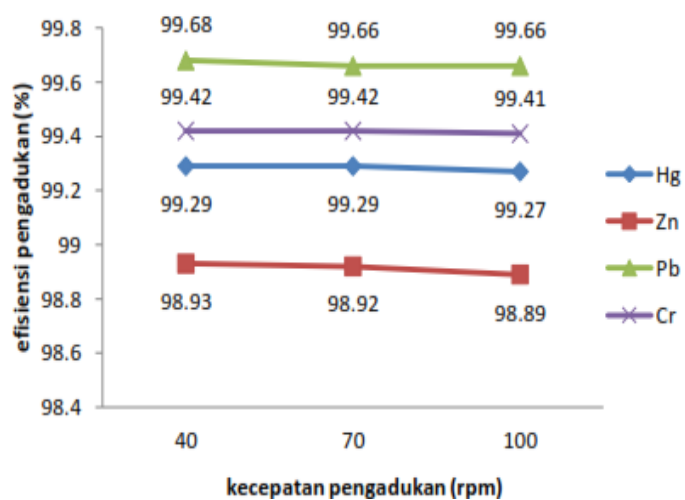

Gambar 8 Pengaruh Variasi Kecepatan Pengadukan terhadap Efisiensi Presipitasi

Variasi kecepatan pengadukan ini dilakukan pada $\mathrm{pH} 10$ dengan konsentrasi $\mathrm{Na}_{2} \mathrm{~S} 30 \%$. Pengaruh variasi kecepatan pengadukan terhadap efisiensi presipitasi dapat dilihat pada Gambar 8. Variasi kecepatan pengadukan dilakukan mulai dari kecepatan pengadukan lambat, sedang, hingga cepat. Pengadukan pada proses presipitasi sulfida ini berfungsi untuk menghomogenkan larutan $\mathrm{Na}_{2} \mathrm{~S}$ yang ditambahkan ke dalam limbah laboratorium agar dapat bereaksi sempurna dan membentuk endapan (Barbooti et al., 2011). Namun pada saat percobaan tidak terlihat perbedaan yang signifikan terhadap efisiensi presipitasi. Kecepatan pengadukan yang digunakan baik lambat, sedang dan cepat tidak berpengaruh terhadap peningkatan efisiensi presipitasi.

\section{KESIMPULAN}

Belerang alam dapat mengendapkan logam berat $\mathrm{Hg}, \mathrm{Pb}, \mathrm{Zn}$, dan $\mathrm{Cr}$ dengan dilarutkan terlebih dahulu menggunakan $\mathrm{NaOH}$ menjadi larutan $\mathrm{Na}_{2} \mathrm{~S}$. pH optimum yang dapat mengendapkan logam $\mathrm{Hg}, \mathrm{Pb}$, $\mathrm{Zn}$ dan $\mathrm{Cr}$ dengan efisiensi paling tinggi adalah $\mathrm{pH}$ 10. Konsentrasi $\mathrm{NaOH}$ yang paling optimal untuk membuat larutan $\mathrm{Na}_{2} \mathrm{~S}$ adalah 30\%. Logam $\mathrm{Zn}$ dan $\mathrm{Cr}$ dapat diturunkan kadarnya sampai memenuhi baku mutu dengan menggunakan larutan $\mathrm{Na}_{2} \mathrm{~S}$ dengan konsentrasi berturut-turut adalah 10 dan 20\%. Efisiensi presipitasi yang dihasilkan berturut-turut adalah 97,93 dan $99,24 \%$.

\section{DAFTAR PUSTAKA}

Adli, H. (2012). Pengolahan Limbah Cair Laboratorium dengan Metode Presipitasi dan Adsoprsi untuk Penurunan Kadar Logam Berat. Skripsi. Universitas Indonesia. Depok.

Amer, S.I. (1998). Treating Metal Finishing Wastewater. Aquachem. Canton.

Andaka, G. (2008). Penurunan Kadar Tembaga pada Limbah Cair Industri Kerajinan Perak dengan Presipitasi Menggunakan Natrium Hidroksida. Jurnal Teknologi 1 (2),109-224

Asmadi, S. Endro, W. Oktiawan. (2009). Pengurangan Chrom (Cr) dalam Limbah Cair Industri Kulit pada Proses Tannery Menggunakan Senyawa Alkali $\mathrm{Ca}(\mathrm{OH})_{2}, \mathrm{NaOH}$ dan $\mathrm{NaHCO}_{3}$. Jurnal Air Indonesia $5(1), 41-54$

Asri, N. P., Abadi, R., Hasmawati, A., \& Mubarok, S. A. (2010). Penurunan Kadar Logam Berat Limbah Cair Industri Emas (PT. X) di Surabaya. Jurnal Teknik Kimia Indonesia 9(2), 55-61

Barbooti M.M, Abid, B.A., \& Al-Shuwaiki, N.M. (2011). Removal of heavy metals usi.ng chemicals precipitation. Eng. \& Tech. Journal 29 (3), 595 612

Cucikodana, Y., Supriadi, A., \& Purwanto, B. (2012). Pengaruh Perbedaan Suhu Perebusan dan Konsentrasi $\mathrm{NaOH}$ terhadap Kualitas Bubuk Tulang Ikan Gabus (Channa striata). Jurnal Fishtech 1 (1),91-101 
Day, R.A \& Underwood, A.L. (2002). Analisis Kimia Kuantitatif. Edisi ke Enam. Erlangga. Jakarta.

Fadlilah, I., Prasetya,A., \& Mulyono, P. (2018). Recovery Ion $\mathrm{Hg}^{2+}$ dari Limbah Cair Industri Penambangan Emas Rakyat dengan Metode Presipitasi Sulfida dan Hidroksida. Jurnal Rekayasa Proses 12 (1), 23-31

Hagemann, S., Oppermann, U., \& Brasser, T. (2014). Behaviour of Mercury and Mercury Compounds at The Underground Disposal In Salt Formations and Their Potential Mobilisation By Saline Solutions. Federal Environment Agency Germany. Umweltbundesamt

Handoko, C.T., Yanti, T.B., Syadiyah, H., \& Marwati, S. (2013). Penggunaan Metode Presipitasi untuk Menurunkan Kadar $\mathrm{Cu}$ dalam Limbah Cair Industri Perak di Kota Gede. Jurnal Penelitian Saintek. 18 (2), 51-58

Ismayana, A. (1997). Proses Presipitasi Kimia sebagai Pengolahan Air Buangan Lanjut Senyawa Ortofosfat. (Tesis). Institut Teknologi Bandung. Bandung.

Khopkar, S.M. (2007). Konsep Dasar Kimia Analitik. Diterjemahkan oleh A. Saptorahardjo. UI Press. Jakarta

La Grega. (2001). Hazardous Waste Management. Mc Graw Hill Inc. New York.

Lewis, A. \& Hille, R.V. (2006). An Exploration Into The Sulphide Precipitation Method and Its Effect on Metal Sulphide Removal. Hydrometallurgy Joural 81(3),197204.

Lusiani, T. (2011). Pengolahan Limbah Cair yang Mengandung Logam Merkuri dengan reaksi Fenton dan Presipitasi
Sulfida. (Skripsi). Institut Pertanian Bogor. Bogor.

Munfarida, A, Haji, A.T.S,Susanawati, L.D., \& Cahyono, H.B. (2016). Reduksi Logam Merkuri (Hg) dengan Penambahan $\mathrm{Na}_{2} \mathrm{~S}$ atau $\mathrm{NaOH}$ pada Limbah Cair Pengujian COD Refluk Terbuka. Jurnal Sumberdaya Alam dan Lingkungan 1(1), 7177.

Naim, R., Kisay, L., Park, J., Qaisar, M., Zulfiqar, A.B., Noshin, M., \& Jamil, K. (2010). Precipitation chelation of cyanide complexes in electroplating industry wastewater. International Journal of Environment Research. 4(4), 735-740

Peraturan Menteri Lngkungan Hidup No. 5 Tahun 2014 Tentang Baku Mutu Air Limbah.

Sidik, A. A. \& Damanhuri, E. (2012). Studi Pengelolaan Limbah B3 (Bahan Berbahaya dan Beracun) Laboratorium-Laboratorium di ITB. Jurnal Teknik Lingkungan 18 (1), 1220

Skants, C. \& Jamali, A. (2012). Evaluation of Treatment Techniques for Mercury Contaminated Leachates. (Thesis. Master of Science). Chalmers University of Technology

Widowati, W., Sastiono, A., \& Jusuf, R. (2008). Efek Toksik Logam Pencegahan dan Penanggulangan Pencemaran. Penerbit Andi. Yogyakarta 
